\title{
THE VIEWS OF WOMEN IN THE LIMPOPO PROVINCE OF SOUTH AFRICA CONCERNING GIRLS' PUBERTY RITES
}

\author{
Dr Thelmah X Maluleke \\ D Litt et Phil \\ Department of Public Health and Centre for Youth Studies, University of Venda \\ Corresponding author:Tmaluleke@univen.ac.za
}

\author{
Prof R Troskie \\ D Litt et Phil \\ Department of Advanced Nursing Science: University of South Africa
}

Keywords: puberty rites; female circumcision; vukhomba; sexuality education; ethnography

\begin{abstract}
This study was a qualitative, exploratory, descriptive and contextual research study, conducted in the Northern Region of the Northern Province (now Limpopo) among Vatsonga/Manchangana in four selected areas. The ethnographic strategy was used to gain access to the puberty rites and to view and describe it from an emic perspective. The techniques for data collection included participant observation, semi-structured interviews, focus group discussions, key informant interviews and feedback workshops. Initiated and uninitiated women view the rite differently. Initiated women see it as an important cultural practice while the uninitiated women see it as a dangerous practice.
\end{abstract}

\section{OPSOMMING}

Die navorsingsontwerp van hierdie studie was kwalitatief, verkennend, beskrywend en kontekstueel, uitgevoer in die Noordelike streek van die Noordelike Provinsie (nou Limpopo), onder die Vatsonga/Manchangana in vier geselekteerde areas. Die etnografiese strategie is gebruik om toegang te verkry tot die pubertiteitseremonie sodat dit vanuit 'n kontekstuele perspektief beskryf kon word. Die insameling van data is gedoen deur middel van deelnemende waarneming, semi-gestruktureerde onderhoude, fokusgroepbesprekings, onderhoude met sleutelinformante en werkswinkels vir terugvoer. Vroue wat die inisiasie deurloop het en dié wat nie geïnisieer is nie se siening omtrent die seremonie het verskil. Geïnisieerde vroue sien dit as 'n belangrike kulturele praktyk, terwyl die ongeïnisieerdes dit as 'n gevaarlike praktyk beskou. 


\section{INTRODUCTION}

Puberty rites are practised in many countries, including South Africa. They have different names in the different language groups where they are performed, and the methods of practice also vary. Among the Vatsonga/ Manchangana it is called vukhomba. According to Junod (1962:175) and Schapera (1946:100), it is called khomba or khoba in Xitsonga. They decided to leave out the prefix $V u$-and it changed the meaning. This will be explained later. Among the Vhavenda, the term "puberty rite" is called vhusha or khomba (Stayt, 1931:100) and it is called kgopa among the Bapedi (Hammond-Tooke, 1981:53). Among the Amampondo the puberty rite is called ukuthomba (Bam [Sa]:1). According to Elam (1998:1) puberty rites of passage occur in every culture, however, there are very few cultures that formally celebrate the passage in a ritual ceremony.

The word vukhomba in Xitsonga is derived from the word khomba that refers to a girl who has reached menarche and is seen as being in the developmental stage. According to Junod (1927:575), the life of an individual among the Vatsonga/Manchangana consists of a succession of stages. The individual proceeds from one stage to another through ceremonies that are connected to a number of taboos. The taboos are strictly observed. Traditionally, girls among the Vatsonga/Manchangana are supposed to go through the puberty rites. With the introduction of Christianity and modern school-based education, girls were discouraged or prevented from attending vukhomba. Some families stopped taking their girls to vukhomba and in some areas a Christian type of vukhomba was introduced. There are therefore two types, the traditional and the Christian. This study concentrates on the traditional vukhomba only.

In this study, vukhomba refers to the traditional rite for girls, which takes place among the Vatsonga/ Machangana exclusively for a girl after menarche. Vukhomba happens anytime after the first menses, for example, a week, months or even years later, depending on the family. It is a period of seclusion and this is referred to as "being in the hut". Vukhomba also denotes an age group. If, for example, a girl who started menstruating one or five years before, goes through vukhomba with the group that has just started menstruating, she is treated as though she is in the same age group as the others. She is expected to respect all those who were initiated before her, even if they are younger than she is.

Another name for vukhomba is ku cineriwa, that is, "danced for"; and one who has gone through the rite is addressed as $U$ cineriwile, that is, "They have danced for you". These statements suggest that the girl does not dance but that other people dance for her. This implies that the initiate watches while others dance. The puberty rites of the Bemba people, called Chisungu, are also described as "dancing the girl" (Richards, 1956:59).

When the girl is undergoing vukhomba, she is called xikhombana. Each girl who is a xikhombana, has a mentor called mudzabi (plural vadzabi). This mudzabi is responsible for the entire needs of the girl and she is the only one who touches her. The initiate does only what the mudzabi tells her to do, and they do it together. The mudzabi is not allowed to leave the initiate unattended. Another important person in vukhomba is the person the girl confided in when she realised she was menstruating. This person is called murileri, meaning "cried to". Murileri is also referred to as mhani wa vukhomba, meaning "mother of the initiate". In each rite there is a chief vukhomba elder who comes from the royal house to supervise the rite, and is usually the traditional leader's wife, mother or sister. The vukhomba elders are post-menopausal women referred to as vatswatsi. In the Iria ceremony of the Okrika tribe of Nigeria, they also use post-menopausal women as the rite supervisors, because of the belief that they are highly spiritual and wise to assist the girls in all stages of their lives (Elam, 1998:1).

The use of "puberty rites" in this study is in line with the definition of puberty rites as defined above by Richards (1956:17). The concept "puberty rites" is used in this study, because the researcher is aware of other initiation rites that girls go through before puberty, for example, musevetho. Since this is the only rite for girls after reaching puberty and menarche, it was found to be proper to use "puberty rites" for vukhomba and avoid confusion.

As in any other initiation, the puberty rites are secretive and are open only to females who have been initiated. 
Furthermore, it is prohibited to talk about the rites in the presence of men and uninitiated females, referred to as maxuvuru. This might mean that information gathered by an outsider might not be a true reflection of what happens. It was for this reason that the researcher found it necessary to go through the twoday adult rite. Studying the rites as an insider gave a more comprehensive picture of what vukhomba is all about. Importantly, it shed more light on the understanding and meaning of vukhomba from initiated women and girls' point of view.

\section{STATEMENT OF THE PROBLEM}

Studies on puberty and initiation rites for girls have been conducted in several countries and within different cultures. However, these studies have different views and meanings about the puberty rites for girls. For example, Mönnig (1967:124-125) views the puberty rites among the Bapedi as rites of passage. Persons (1990:47-49), in a study conducted among the Basanga in South Zaire, suggests that the initiation rites are a transition stage from childhood to adulthood. It is about acculturation into a new social group and accepting responsibility for a person's own behaviour. While Krige and Krige (1947:113) suggest that girls go through harsh treatment which is looked upon as discipline. The initiates are instructed in the rules related to the stage the girl is now entering. She is also warned to be careful in any sex play with boys because she will fall pregnant.

According to Stayt (1931:106) during the puberty rites, girls are taught the cultural rules of etiquette and obedience, and given sexuality education. Schapera (1946:100) also suggests that girls are warned not to sleep with boys before marriage. The International Confederation of Midwives and World Health Organization (2000:6) suggests that during the initiation rites the initiates are taught about sex and encouraged to become sexually active.

Girls' initiation ceremonies are rites of passage where the initiates change from one state of being to another, that is, from childhood to womanhood. Initiation rites are seen as an expression of fundamental social values, the focus of which is on relations established by marriage and the community. Furthermore, initiation rites create solidarity among women and are used for passing knowledge from one generation to another. The initiation rites use secret language to teach the initiate (Rasing, 1995:99).

Paige and Paige (1981:18) refer to the initiation rites for girls as the menarche rites and describe it as mechanisms for initiating girls into adulthood. Richards (1956:17) refers to it as puberty rites or female initiation ceremonies. Puberty rites mark the attainment of menarche as a sign of sexual maturity, fertility and social maturity. Lincoln (1981:90) refers to it as women's initiation, a process that a woman goes through, resulting in a change of status and becoming "fertile, productive, experienced and whole".

The above mentioned studies were mainly conducted by men who were missionaries in these areas. Literature suggests that puberty rites are secretive and therefore it is very difficult to get information about them. "Information regarding initiation is extremely difficult to obtain particularly for a male researcher" (Mönnig 1967:1124). This difficulty results from the fact that it is taboo to discuss female initiations with men. This might suggests that the views about puberty rites expressed in these studies are mainly from the male perspective. It would be important to find out whether initiated women and girls share the same sentiments expressed above about vukhomba. It would be interesting to get the meaning and views about vukhomba from the women and girls participating in the initiation. Furthermore, it would also be interesting to get the views of the uninitiated women and girls about it.

\section{PURPOSE OF THE STUDY}

The purpose of this study was to explore and describe the views of initiated and uninitiated women and girls about puberty rites for girls.

\section{RESEARCH OBJECTIVES}

The objectives of the study was to:

- determine the meaning of vukhomba from the initiated and uninitiated women and girls' point of view; and

- explore and describe the views of initiated and uninitiated women and girls about vukhomba. 


\section{STUDY DESIGN}

The study was designed as a qualitative, exploratory, descriptive and contextual research project conducted in the Northern Region of the Limpopo Province of South Africa among the Vatsonga/Manchangana in four selected villages. The ethnographic strategy was used to gain access to the vukhomba to view and describe the rites from an emic perspective. The researcher spent time with the community to develop rapport and identify potential sources of bias. Qualitative approaches allowed the researcher to explore reality from the perspective of the participants - the emic perspective. Furthermore, qualitative research approaches are described as an inductive and interactive process that gives a holistic perspective of a cultural event. In this study much attention was paid to the meaning, understanding, and experiences of the research subjects (Brink, 1996:12, 119). During this research, the researcher spent a total of four weeks in the actual puberty rites. This enabled the researcher to closely observe the participants. The rites took place in the cultural environment, which enabled understanding of the experiences of the participants. Post vukhomba interviews made it possible to examine the initiates' views about the rites.

This study described and analysed vukhomba as a cultural practice and the activities, events and views of the different participants in order to provide a comprehensive report of this cultural event. Participant observation, interviews and audiotapes were used to collect data. This enabled the researcher to explore the process, meaning, and understanding of the vukhomba.

\section{DATA COLLECTION}

Data were collected from January 1998 to July 1999. Feedback workshops were conducted from February to March 2000 to verify the information collected with initiated elders and with women and girls in the participating communities. Data collection was carried out using the following methods: participant observation, key informant interviews, focus group discussions and semi-structured one-to-one interviews about puberty rites. Feedback workshops were also conducted to verify the information and interpretation of data. See Tables 1 and 2.
In this study the population included all girls who were initiates during January 1998 and December 1999 at the selected villages, and all participants in the initiation. One puberty rite in each of these villages was studied. The selection of the puberty rites was done through a random sampling method. The puberty rites scheduled during the time of the study in each village were listed and one rite was selected. This was done to reduce sampling bias. Purposive nonprobability sampling was used to select subjects who participated in the focus group discussions, and key informant interviews. This method was used to select individuals who were involved in initiation and had knowledge about vukhomba. Secondly it gave the researcher an opportunity to select subjects who represent individuals who had no knowledge of what was happening in the initiation and were also not participating in them. The advantage of the purposive non-probability sampling is that it gives the researcher an opportunity to select the sample based on knowledge of what is being studied. Its disadvantage is that it easily lends itself to sampling bias, and generalisation of the results is very limited (Brink, 1996:141).

\section{Reasons for selecting these villages}

Originally four villages were selected, however, the researcher did not get permission to conduct the study in one of the villages. The four villages were chosen because:

- they are not more than 100 kilometres away from one another for possible travelling between villages. This would save costs as well as time involved in travelling;

- the majority of the inhabitants are Manchangana/ Vatsonga, the group on whose puberty rites (vukhomba) the study was based; and

- of their historical and socio-political background.

Table 1 shows the research methods/techniques, the total number of focus group discussions and interviews conducted and the number of participants or respondents for each instrument.

\section{Participant observation}

Participant observation was conducted in the three villages where permission was granted. The re- 
Table 1: Research methods/techniques

\begin{tabular}{|l|l|l|}
\hline Research instrument & $\begin{array}{l}\text { Total number of } \\
\text { discussions } \\
\text { conducted }\end{array}$ & $\begin{array}{l}\text { Total number of } \\
\text { participants or } \\
\text { respondents }\end{array}$ \\
\hline $\begin{array}{l}\text { Focus group discussion with vukhomba } \\
\text { elders }\end{array}$ & 3 & 29 \\
\hline $\begin{array}{l}\text { Focus group discussion with initiated } \\
\text { women }\end{array}$ & 3 & 41 \\
\hline Focus group discussion with initiated girls & 3 & 28 \\
\hline $\begin{array}{l}\text { Focus group discussion with church } \\
\text { women }\end{array}$ & 1 & 15 \\
\hline $\begin{array}{l}\text { Focus group discussions with girls who } \\
\text { have reached puberty (Thugamama) }\end{array}$ & 1 & 6 \\
\hline Semi-structured interviews with murileri & 1 & 3 \\
\hline Semi-structured interview with parents & 3 & 3 \\
\hline Semi-structured interview with mudzabi & 3 & 4 \\
\hline $\begin{array}{l}\text { Semi-structured interview with initiates } \\
\text { Key informant interviews: Chief supervisor } \\
\text { of vukhomba }\end{array}$ & 6 & 6 \\
\hline $\begin{array}{l}\text { Key informant interviews: Traditional } \\
\text { leaders }\end{array}$ & 4 & 3 \\
\hline Key informant interviews: Teacher & 3 & 101 \\
\hline Key informant interviews: Church elder & 1 & $\mathbf{2 4 7}$ \\
\hline Feedback workshops & 9 & 3 \\
\hline Total & $\mathbf{3 8}$ & 3 \\
\hline
\end{tabular}

Table 2: Average number of participants in each initiation

\begin{tabular}{|l|l|l|l|}
\hline Category of initiation participants & Village 1 & Village 2 & Village 3 \\
\hline Number of initiates & 1 & 3 & 2 \\
\hline Number of vadzabi & 1 & 1 & 2 \\
\hline Number of varileri (plural of murileri) & 1 & 1 & 1 \\
\hline Average number of initiated girls per day & 26 & 21 & 16 \\
\hline Average number of initiated women per day & 17 & 10 & 13 \\
\hline Average number of vukhomba elders per day & 11 & 15 & 8 \\
\hline Total & $\mathbf{5 7}$ & $\mathbf{5 1}$ & $\mathbf{4 2}$ \\
\hline
\end{tabular}


searcher stayed in the village in order to gain access to the events and activities in the life of an initiate. The researcher attended one randomly selected vukhomba in each area and was present during all the steps of the ritual. The researcher spent days and nights in these villages. In this way an in-depth study of the puberty rites was done in three villages. Table 2 indicates the average number of people per initiation. The researcher was only allowed to use an audiotape to record the proceedings during the initiation. Since the light in the initiation area was poor, note taking was not possible. Transcriptions of the recordings were done immediately after each session in a well-lit area.

\section{Semi-structured interviews}

Semi-structured interviews were held with six initiates, four vadzabi, three parents of the initiates, and three murileri. In the semi-structured interviews, guidelines were used to guide the researcher through the interviews. The guidelines consisted of questions and topics that needed to be covered. The interview guidelines also allowed the researcher to probe for more information. This flexibility allowed the researcher to follow new directions in the discussions. The abovementioned people were interviewed at different times in different areas where they were found (Brink, 1996:158; Hudelson, 1994:12-13; Maier, Gorgen, Kielmann, Diesfeld \& Korte, 1994:18).

\section{Focus group discussions}

Focus group discussions were conducted with the vukhomba elders, initiated women, uninitiated and initiated girls (see Table 1). The focus group discussions were held with each group on different days to prevent the groups from influencing one another. The data gathered through tape recordings were later transcribed word for word by the researcher.

A focus group discussion is described as "a group discussion with people who have been selected, because they share certain characteristics, which are relevant to the topic to be discussed." It is a planned discussion usually comprising six to ten people and is designed to obtain information on participants' beliefs and perceptions within a defined area of interest (World Health Organization, 1994:24). In this study focus group discussions were used for getting the beliefs and perceptions of the subjects about the vukhomba. A structured focus group discussion set of guidelines was used to ensure that all the relevant issues were covered (Hudelson, 1994:22; World Health Organization, 1994:27-28).

\section{Key informant interviews}

A total of eleven key informant interviews were conducted, four with traditional leaders, three with the chief supervisor of vukhomba (Phorisa ra vukhomba), three with teachers and one with a church elder (see Table 1). It was difficult to get males to participate as key informants and also to get information from male informants, because the majority of them felt they had limited knowledge about the initiation of girls. Furthermore, the male informants seemed uncomfortable about discussing vukhomba, and immediately referred the researcher to women. Since the discussions about vukhomba seemed to be causing uneasiness among the males, the researcher respected their feelings and did not pursue the reasons for their uneasiness.

Key informant interviews are interviews that are conducted with people who have a special position in the community. Key informants possess special knowledge and are willing to share this with the researcher. They have access to the culture under study in a way that the researcher lacks (Hudelson, 1994:43).

\section{Feedback workshops}

According to Broerse (1998:209), feedback workshops are conducted in qualitative research to give the respondents an opportunity to review and criticise the findings, legitimise them, allow room for new contributions, and enhance the visibility of the community needs. In this study nine feedback workshops were conducted, three in each village.

The workshops were conducted, firstly, to verify the information collected through the above-mentioned instruments. The workshop participants made corrections and additions to some aspects of the reports presented. The corrections and additional information were recorded and changes incorporated in the final report. The researcher also had a list of concepts that needed clarification, and this was done. 
A set of guidelines was used to guide the workshop process.

\section{DATA ANALYSIS}

The collected data were transcribed verbatim from the tape recordings, translated into English, and analysed. Individual analysis of the transcriptions was done and categories were formed to allow the researcher to identify similarities, differences and relationships. The developed categories were then grouped into themes: The meaning of vukhomba; perceptions and myths related to the puberty rites; the views of the initiated women about vukhomba; and the views of the uninitiated women about vukhomba.

The key informant interviews and semi-structured interviews were analysed, using the Maier et al. (1994:86) steps of data analysis as a guide to developing categories from tape recordings. The analysis of focus group discussions and recordings during initiation were examined using Creswell's (1994:154-156) steps of data analysis as a guide to developing categories from tape recordings. The analysis and findings were presented to the participants in a feedback workshop for their inputs and verification. The assistance of peers was also sought to help with the examination of transcripts and field notes to ensure reliability. A professional translator was used to check the English version and some parts that needed the expertise of a translator. The independent coders, translator and peers were women who had to sign an agreement not to disclose any information about vukhomba.

\section{VALIDATION OF DATA}

As already mentioned above, the preliminary data analysis and findings were presented to the participants in a feedback workshop for their inputs and verification. Secondly, triangulation was used for the purpose of generating and validating meaningful data (Streubert \& Carpenter, 1995:318).

\section{CREDIBILITY AND CONFIRMABILITY}

The researcher stayed in the research setting for the full period of the initiation. Different methods/ techniques were used for data collection. Notes, tape recordings, pictures and video recordings of different activities were involved. Data generated by each method were first analysed separately and then triangulated with the other methods. The collected data were also given to peers with clear written instructions to check the transcripts and field notes to ensure credibility and to categorise and develop themes from the data. The categories and themes were compared with those identified by the researcher. There were similarities and differences in the categories and themes. Similar themes were adopted as themes for the analysis and the differences were re-examined and regrouped and given new names. The use of the feedback workshop strengthened the credibility of the study. The analysed information was then compared with other findings.

\section{TRANSFERABILITY AND DEPENDABIL- ITY}

Four areas were identified using purposive sampling of the research areas. In each area one puberty rite was chosen through random sampling. Different methods were used to collect data. The data were transcribed, translated, coded and analysed individually. Coding of the data was done through highlighting words and phrases that appeared frequently. These were grouped together in categories. The categories from the data collected by different research instruments were grouped into themes, which were compared with each other, including analysis by peers.

\section{LIMITATIONS OF THE STUDY}

The study was limited to a small area and a small group of the population and therefore the results may not be representative enough. The study concentrated on only one type of puberty rite for girls within one cultural group, making it difficult to generalise the findings as being representative of all puberty rites in the Northern Region. The fact that the puberty rites are secret could have influenced the respondents to withhold some information that they regarded as highly confidential. Another limitation was that the privacy of informants could have been invaded in the process of the study. 


\section{ETHICAL CONSIDERATIONS}

The research proposal was presented to the Research and Publications Committee of the University of Venda for ethical consideration, and was approved. It was also sent to the Regional chairman of the Congress of Traditional Leaders of South Africa (CONTRALESA) for approval. The researcher was advised by the CONTRALESA chairperson to seek permission from the four traditional authorities where the research was to be conducted. Permission to meet with the vukhomba elders was granted in the meetings held with the traditional authority in the study areas. Permission was also sought from vukhomba elders in the areas where the study was conducted. The researcher also went through the adult rites in order to be allowed into the vukhomba. Anonymity of the participants was maintained and an assurance was given that all information would be treated in absolute confidence. This would include all records of the information collected, in written and audiotaped format. All participants were assured of the maintenance of confidentiality and the informed consent of all the participants was obtained. Since vukhomba is a secret ritual, the researcher had to obtain special permission to place copies of the thesis in libraries, and to publish material from it. The vukhomba elders granted her the necessary permission.

Table 3: Perceptions and myths related to the puberty rites for girls

\begin{tabular}{|c|c|c|c|}
\hline \multirow[t]{2}{*}{ Category } & \multirow[t]{2}{*}{ Responses } & \multicolumn{2}{|c|}{ Frequencies } \\
\hline & & Initiated & Uninitiated \\
\hline \multirow[t]{2}{*}{ Culture } & Cultural practice, promotes culture, ubuntu & 6 & 0 \\
\hline & Evil cultural practice & 0 & 3 \\
\hline \multirow[t]{3}{*}{ Traditions } & $\begin{array}{l}\text { Place where girls learn traditional life and dances; } \\
\text { traditional school }\end{array}$ & 6 & 0 \\
\hline & Useless practice & 0 & 2 \\
\hline & $\begin{array}{l}\text { No quarrels in the community, creates a happy mood } \\
\text { in the community }\end{array}$ & 3 & 0 \\
\hline \multirow[t]{3}{*}{ Social } & Place where women enjoy themselves & 3 & 0 \\
\hline & $\begin{array}{l}\text { Place for entertainment, women coming together to } \\
\text { enjoy themselves }\end{array}$ & 3 & 0 \\
\hline & $\begin{array}{l}\text { Telling the public that the girl is now ready to get } \\
\text { married }\end{array}$ & 1 & 0 \\
\hline \multirow[t]{6}{*}{ Myths } & $\begin{array}{l}\text { Cutting of private parts and making the initiate eat the } \\
\text { cut flesh; cut and join the vagina to the anus, cutting of } \\
\text { genitals, stretching of labia minora }\end{array}$ & 0 & 8 \\
\hline & $\begin{array}{l}\text { Insertion of horn, maize cob or clay penis into the } \\
\text { vagina }\end{array}$ & 0 & 5 \\
\hline & Makes initiates eat food mixed with their own faeces & 0 & 1 \\
\hline & Uninitiated will not have children & 0 & 1 \\
\hline & $\begin{array}{l}\text { There is a monster that comes at night to swallow the } \\
\text { initiates }\end{array}$ & 0 & 1 \\
\hline & Girls are taught to be submissive to men & 0 & 1 \\
\hline
\end{tabular}




\section{RESULTS AND DISCUSSIONS}

The perceptions and views of initiated and uninitiated women and girls about the puberty rites are different. The uninitiated women and girls perceive vukhomba as an evil and dangerous practice, while the initiated perceive it as a form of entertainment and a safe refuge for women from harassment and violence by their male partners. Men see the rite as privacy for women and a space they cannot invade. In the community vukhomba is a respected ritual that the community identifies with. Table 3 indicates the perceptions and myths related to the puberty rites for girls as perceived by initiated and uninitiated women and girls.

\section{Perceptions of uninitiated women and girls}

The perceptions of uninitiated women and girls could be categorised into culture, tradition, social activities and myths. Since there is a close relationship between culture and tradition, these categories are discussed together.

\section{Culture and tradition}

Uninitiated women see vukhomba as a dangerous cultural practice. It is evident that uninitiated women have a limited knowledge of the rite, leading to false assumptions and perceptions about it and its practice. In the two focus group discussions with uninitiated women and girls, and also in the interview with the teacher, the puberty rites were described as a useless cultural practice that teaches girls to misbehave. The participants were of the view that since this rite is kept secret and obscene language is used, therefore vukhomba is evil. If female circumcision and the insertion of a horn into the initiates' vagina were done in vukhomba then the uninitiated women and girls would be justified in calling it evil. These could deter girls from being initiated. However, the secrecy around the rite does not allow them to verify their information. In other words, there is no way of verifying this information unless one is initiated.

The arrival of missionaries in the areas where the initiation of women was taking place also contributed to the perception that initiation is evil. All missionaries were opposed to initiation in the communities where they were operating. The result of this was that most
Christian families stopped taking their children for initiation, while non-Christians continued (Mönnig, 1967:112).

\section{Social}

Although the uninitiated women and girls do not view vukhomba as a place of entertainment, they participate in the community celebrations that happen at the end of the initiation period.

\section{Myths}

Uninitiated women and girls believe that in the puberty rites the vukhomba elders insert a horn into the girl's vagina and cut her clitoris. However, none of them had seen a woman who had been circumcised. Although some of the participants had initiated friends, their friends would not discuss what happens during the puberty rites. It was indicated in one focus group discussion that men also hold this perception about the rite. "Teacher $Z$ would call you and ask you to carry his books to the staff room. When you get there he would propose to you and when you refused he would say his penis is smaller than the horn that you were carrying around for the whole week." No evidence of female circumcision was found.

There is a general perception among uninitiated women and girls that initiates are taught about sexual relationships with men, which results in teenage pregnancies. According to the International Confederation of Midwives \& World Health Organization (2000:6) during puberty rites girls are taught about sex and also encouraged to practise it. This view was also shared by a participant who said: "Initiated girls like men, which means that they are taught about sexual relationships with men and they are putting that into practice without any knowledge of contraception and getting children." On the other hand, it was indicated that there was no difference regarding teenage pregnancies between the initiated and uninitiated girls.

Initiated women also indicated that teenage pregnancy is a problem in the villages for both initiated and uninitiated girls. They further suggested the inclusion of contraceptives in what is taught in vukhomba. The inclusion of contraceptives in the intervention programme was also suggested in the feedback, but the vukhomba elders were totally opposed to this. The 
researcher had to leave it out of the intervention programme. The vukhomba elders believe in abstinence until marriage, which is not happening, and they are not prepared to accept an alternative. Abstinence is also recommended for the prevention of HIV/AIDS.

Some sexuality education teachers in the United States of America also hold this view. A study by The Alan Guttmacher Institute (2000:1) suggests that sexuality education teachers in the USA's public schools focus on abstinence-only as the only way of preventing pregnancy and sexually transmitted diseases: “... teachers think that students who receive sexuality education that stresses abstinence are less likely to have intercourse than students who do are.... teachers think that students who are taught to use contraceptives if they are sexually active are more likely to do so than students who do not receive similar instruction" (The Alan Guttmacher Institute, 2000:1).

The uninitiated women felt that vukhomba must be stopped, because it is dangerous for the girls. One participant said: "Do you think people can just give these girls many presents for nothing? They give them presents to make up for the ordeal they have been subjected to." Another one said: "It is true that girls, unlike boys, do not go to the hospital after the circumcision, but I think it is because women are stronger than men when it comes to pain."

Vilakazi-Tselane and Mbere (1998:5) classified puberty rites among the Vhavenda as dangerous cultural practices, because of the presence of genital mutilation. However, no evidence of the presence of genital mutilation was cited in their study. According to Khupiso (2000:2), female circumcision is practised in some parts of South Africa. It was reported that two teenagers were abducted and forcefully circumcised. The researcher followed up the incident at the hospital mentioned by the journalist, but did not find information related to the incident. No evidence of genital mutilation could be found in the puberty rites attended. However, more studies on female initiation among other South African groups are needed to establish whether female circumcision is a myth or a reality in South Africa.

It is well documented that female circumcision is practised in some parts of Africa to maintain virginity, for example, in Egypt the courts have legitimised female circumcision. A Demographic Health Survey conducted in 1995 indicated that 97 percent of married women between 14 and 49 years of age had been circumcised. These women had had their clitoris partially or totally removed and their labia minora removed. In severe cases the external genitals are removed, and the vaginal opening reduced to just a very small opening (El-Sayed, 1997:17).

Uninitiated girls who had reached puberty (Thugamama) had mixed feelings about initiation. Some of them wanted to be initiated, but were afraid. Their fears were mainly related to the general belief held in the community that during the puberty rites the vukhomba elders insert a horn into the initiate's vagina. One of the participants mentioned that her mother had told her that in the vukhomba the initiates are made to eat food mixed with their own faeces. Another one was told that a monster visits the initiation hut at night to swallow the initiates. It seems in these cases that the myths were used to discourage these girls from attending the initiation. However, in some instances myths are used to encourage girls to be initiated. For example, in the focus group with Christian women one of the uninitiated women indicated that her grandmother told her that she would not be able to get children if she is not initiated.

There was no mention of the stretching of the labia minora in any of the focus groups and interviews. This was also not observed in any of the initiations. This question was raised at the feedback workshops. It was indicated in the feedback workshops that stretching of the labia is not done during vukhomba. It is done by young girls and is called ku tlangisa. The children are instructed to do this procedure by their mothers and grandmother. The stretching of the labia minora takes place before menarche, because it is believed that the labia minora cannot stretch after the first menses.

\section{Perceptions of initiated girls, initiated women and vukhomba elders}

\section{Culture and tradition}

Initiated women and girls view the rite as a cultural practice that upholds the African culture. They described it as a school where women other than their own mothers teach initiates the facts of life. They are 
taught ubuntu and respect for elders and for one another. Puberty rites also prepare girls for acceptable behaviour in their culture (International Confederation of Midwives \& World Health Organization, 2000:6). They are also taught about their culture through poetry, dances, singing and story-telling. According to Schapera (1946:99), puberty rites offer formal education, which plays an important role in the life of an individual. Richards (1956:26) views puberty rites as ways of raising the name or enhancing the social reputation of the adolescent and family. Puberty rites among the tribes of erstwhile Tanganyika, the present Tanzania, are viewed as a symbolic rebirth and the creation of a new useful member of the tribe (Cory, 1956:27-29).

Initiated women described vukhomba as a rite to mark the end of puberty (Thugamama) and the beginning of girlhood (nhwanyana): a place for teaching a girl the facts of life and women's work. The initiates learn to respect elders and to listen to them. Furthermore, it teaches traditional dances and milawu to initiates. The rite encourages the girls to maintain their virginity by stressing no sex before marriage. "People have thrown away this tradition. Look at the girls nowadays they get married and have children at a very young age and suffer from ricilana...". Ricilana is a disease; the signs and symptoms of which resembled those of cervical cancer. Initiated women felt that vukhomba is a cultural practice that upholds African culture.

\section{Social}

Initiated women and girls view vukhomba as a place where they enjoy themselves without fear. It is also a safe place for women to use language that is not normally used and which is considered vulgar by the community. It offers an environment where women feel free to perform nude dances. One participant said: "Vukhomba is a safe environment, because what you do or say in there will never be known by the outside world."

Vukhomba teaches respect and vumunhu or ubuntu. It teaches them traditional dances and how to greet and relate to people and family members. "Before I was initiated I used not to greet people when I met them, but after initiation it was difficult for me to pass a person without greeting." It seemed as if this initiated girl had been transformed from what she was before the initiation. This transformation, according to Lincoln (1981:91), is the ultimate aim of the initiation.

In relation to the use of obscene language in vukhomba, they felt that obscene language deters men from coming close to the area where the initiation is taking place. Although the participants only refer to males, they also use words that are not normally used to describe female reproductive organs. Vukhomba tries to preserve the language and to teach the initiate correct concepts, for example, in normal day-to-day language in the community the reproductive parts of a woman and man are referred to as the front of a woman or the front of a man (hala mahlweni ka wansati and hala mahlwane ka wanuna). The front of a person can mean many things. The use of the correct names for these body parts is considered vulgar or obscene in the community. The only acceptable place to learn the correct names is during the initiation, and the initiate is told not to use the words in public. This is different from learning them on the streets, because they are usually used in a derogatory manner to insult people. The uninitiated women and girls learn about them on the streets.

Some initiated women (2) felt that the puberty rites create a happy mood in the community, because quarrels or fights are not allowed when there is a puberty rite going on in the village. Anyone who contravenes this is fined or physically punished by the women. Women appeared to be in charge of the villages during all the vukhomba observed by the researcher. It seems as though vukhomba enhances the power of women. The traditional leader has no power over the decisions made by these women. It is important to mention at this stage, however, that women can only take decisions on issues that contravene the taboos and rules related to vukhomba. Other village issues are still the responsibility of the traditional leader.

According to Lutkehaus and Roscoe (1995:20-21), the Rauto puberty rites in Melanesia are concerned with fertility, power and social regeneration. It is sometimes viewed as a form of love magic, because its principal aim is to make the initiates attractive to men. It enhances the beauty, social attractiveness and health of the initiate. The Manam puberty rites are also concerned with health, growth and personal attraction, and 
are associated with the beauty and sexual desirability of women and men. The attention that is given to physical appearance signifies a cultural theory of the relationship between beauty and power. Although it is not mentioned in any of the discussions with informants, the gifts that the girl receives suggest that they want her to look beautiful and attractive (Lutkehaus \& Roscoe, 1995:21).

Mönnig (1967:112) describes the initiation of the youth among the Bapedi as a sacred institution that is the cornerstone of the whole social and political organisation. It is a way in which the individual acquires the status of citizenship of the tribal community, which will allow her full participation in the social, political and juridical activities of the community.

The initiation ceremonies prepare the initiates for a new step in the life of the individual. The ability to bear children and the strength, courage and endurance needed in daily work were identified by Schapera (1946:107) as the qualities necessary to succeed in life. Furthermore he praised the initiation for managing to inculcate obedience, discipline and general good behaviour among the initiated. The focus of puberty rites is a social rather than a natural change. Initiations are public affairs, though the activities and knowledge gained are kept secret. The purpose of all initiations is to transmit knowledge and powers that are exclusive to the initiated. Lincoln (1981:90) views the initiation as a way of transforming a girl and radically separating her from her childhood existence. Furthermore, initiation for girls endows the lives of women with a sense of the meaning and dignity of their status in the community. The emphasis in the initiation is on learning new skills.

\section{Myths}

The cutting of the clitoris and insertion of the horn were indicated by the initiated women as ways of detecting uninitiated people. "Uninitiated people always mention these things, even your own husband believes that these strange things happened to you. They do not believe when we tell them the truth about the initiation. So, we just let them what they want to believe".

The views of the initiated girls about vukhombabefore they themselves were initiated, were similar to those of the uninitiated discussed above. They also referred to the issue of the clitoris cutting and the insertion of a horn in the vagina. The majority of the girls indicated that they expected the cutting of the clitoris and the insertion of the horn. It was quite disturbing to realise that despite all the stories young girls had heard about the rite, they were still willing to subject themselves to the practice. According to Mashego (1997:26-116), female circumcision is done in the Bushbuck Ridge area among the Mapulana people. An investigation is necessary to confirm the reality of this and to protect the young females from these "unkindest cuts".

Although there is no evidence of genital mutilation, evidence of beating in the initiation can still be found. In one of the initiations observed, the initiate's sister beat the initiate because she failed to cry when she was requested to. According to Schapera (1946:100), at the vhusha rite the initiates are beaten and made to stand in water. In the three puberty rites that the researcher attended as a participant observer, no cutting of the clitoris or insertion of a horn was observed. The only horn (Kudu's horn) the researcher saw during the initiations was the one that is blown now and then. Another observation was that the vadzabi were the only people allowed to touch the initiate, because other people might bewitch her and render her infertile.

\section{CONCLUSION AND RECOMMENDATIONS}

The perceptions and views of initiated and uninitiated women and girls about the puberty rites are different. The uninitiated women and girls perceive the rite as an evil and dangerous practice, while the initiated view it as a form of entertainment and as a safe refuge for women from harassment and violence by their male partners. Initiated women, on the other hand, view vukhomba as a place of fun and freedom that teaches respect and ubuntu among the youth.

It was evident that unintiated women have limited knowledge about vukhomba, leading to false assumptions and perceptions of the rite. There is a general view among the uninitiated females that female circumcision is practised in the initiation. But there is no evidence of female circumcision in the initiation and even the vukhomba elders have not experienced it. The origin of these myths is not known and the reasons for their existence are not known. 
The initiated women seem to be responsible for the misinformation about vukhomba. It seems as if this practice started long ago and that initiated women are not doing anything to correct it. No evidence could be found that positively linked female circumcision to vukhomba in people's living memory. These myths and misinformation could be part of keeping the rite secret. On the other hand, it could be that the initiated females realise that the uninitiated are entitled to their opinion and leave them to say what they want about vukhomba.

The perceptions that are held about vukhomba are also working against what the rite plans to achieve to prevent sex before marriage. An example is the belief that the men have that once a girl is initiated she is in a position to have sex, because in the initiation a horn was inserted into her vagina and she managed to carry it around. Another problem is that the uninitiated people do not believe that these things do not happen in the vukhomba. The secrecy around the rite also adds another dimension that makes it difficult for the uninitiated to believe that these things do not happen and that the initiated girl is just a girl like any other.

Although initiated and uninitiated women hold different views about vukhomba, however, vukhomba among Vatsonga /Manchangana is a respected cultural event, the end of which is celebrated by the whole community, young and old, educated and non-educated, initiated and non-initiated. Puberty rites for girls are important for uniting women in the community to claim their position in the society. The problem with this acquired position is that it is temporary. The question is how one makes sure that women retain their power after the ceremony. One must try and refrain from labelling all African practices as evil without knowing the facts.

Further studies should be done on puberty rites in different communities to find out if there are health risk practices that might threaten the lives of the initiates. The Department of Culture and Technology should recognise puberty rites as one of the important heritages of South Africa. The communities still see vukhomba as an important rite for girls and this should be seen as a cultural heritage.

\section{REFERENCES}

BAM, N [Sa]: Adolescence in the Pondoland Area of Transkei.
Unpublished.

BRINK, HI 1996: Fundamentals of research methodology for health care professionals. Kenwyn: Juta.

BROERSE, JEW 1998: Towards a new development strategy. Delft: Eburon.

CORY, H 1956: African figurines: Their ceremonial use in puberty rites in Tanganyika. London: Faber \& Faber.

CRESWELL, JW 1994: Research design: Qualitative and quantitative approaches. Thousand Oaks: Sage.

ELAM, J 1998: A cross-cultural comparison of puberty rites and ceremonies for females. The Oxford Review Web Site, http:// www.emory.edu/OXFORD/Publications/Review/puberty.html.

EL-SAYED, H 1997: Egyptian court legitimises female circumcision. Women's Health News, 24:17-18.

HAMMOND-TOOKE, WD 1981: The tribes of Willowvale district. Pretoria: Dept of Native Affairs.

HUDELSON, PM 1994: Qualitative research for health programmes. Geneva: World Health Organization Mental Health Division.

INTERNATIONAL CONFEDERATION OF MIDWIVES \& WORLD HEALTH ORGANIZATION 2000: Frontier of midwifery care: STDs/ HIV/AIDS in safe motherhood. Pre-congress workshop 19-22 May 1999 Manila, Phillipines.

JUNOD, HA 1927: The life of a South African tribe. London: Macmillan.

JUNOD, HA 1962: The life of a South African tribe; 2 nd edition. New York: University Books.

KHUPISO, V 2000: Teens tell of abduction and forced circumcision.

City Metro, 30 January: 2.

KRIGE, EJ \& KRIGE, JD 1947: The realm of the rain queen. London: Oxford University Press.

LINCOLN, B 1981: Emerging from the chrysalis: studies in rituals of women's initiation. Cambridge: Harvard University Press.

LUTKEHAUS, N \& ROSCOE, PB 1995: Gender rituals: female initiation in Melanesia. New York: Routledge.

MAIER, B; GORGEN, R; KIELMANN, AA; DIESFELD, HJ \& KORTE, R 1994: Assessment of the district health system using qualitative methods. London: Macmillan.

MASHEGO, G 1997: The unkindest cut of all. True Love, December:26-116.

MÖNNIG, HD 1967: The Pedi. Pretoria: JL van Schaik.

PAIGE, KE \& PAIGE, JM 1981: The politics of reproductive ritual. Los Angeles: University of California Press.

PERSONS, DN 1990: Teach them unto your children: Contextualization of Basanga puberty rites in the United Methodist Church. Ann Arbor: U. M. I.

RASING, T 1995: Passing on the rites of passage: Girls' initiation rites in the context of an urban Roman Catholic community on the Zambian Copperbelt. Amsterdam: African Studies Centre. 
RICHARDS, AL 1956: Chisungu: A girl's initiation ceremony among the Bemba of North Rhodesia. London: Faber \& Faber.

SCHAPERA, I 1946: Bantu speaking tribes of South Africa: an ethnographical survey Cape Town: Maskew Miller.

STAYT, HA 1931: The Bavenda. Oxford: Oxford University Press. STREUBERT, HJ \& CARPENTER, DR 1995: Qualitative research in nursing: Advancing the humanistic imperative. Philadelphia: JB Lippincott.

THE ALAN GUTTMACHER INSTITUTE 2000: Trends towards abstinence-only sex-ed means many US Teenagers are not getting vital messages about contraception. New York News Release Website, http://www.agi-usa.org/pubs/or_teen_preg_decline.html VILAKAZI-TSELANE, L \& MBERE, N 1998: A situational analysis of the girl child: A research report for NIPILAR. South Africa: NIPILAR.

WOODS, NF \& CATANZARO, M 1988: Nursing research: Theory and practice. Washington DC: Mosby.

WORLD HEALTH ORGANIZATION 1994: Qualitative research methods: teaching materials from a TDR workshop. Geneva: WHO. 